\title{
Business Value of Facebook: A Multiple Case Study from a Developing Country
}

\author{
Ashir Ahmed \\ Faculty of Business and Law \\ Swinburne University of Technology, Australia \\ azahmed@swin.edu.au \\ Mubasher Ibrahim \\ Hailey College, Pakistan \\ ibrahimmubasher@hotmail.com
}

\begin{abstract}
Social media applications such as Facebook, Twitter and Instagram are used by firms to create business value. Small companies, generally referred as small to medium sized enterprises (SME) are predominantly interested in using these applications because of the low cost associated with their usage, low barriers to participation as low level of IT-skills required to use them. SMEs can use social media for a variety of tasks such as marketing, community building and customer relationship management. This study examines the use of Facebook among SMEs in a developing country and aims to extend the existing understanding of how SMEs create business value by using Facebook. A multiple case study approach is used as a research methodology involving five SMEs from Pakistan. In depth interviews were conducted with the key informants of these SMEs to find out why they are using Facebooks and what business value has been created from such usage. It is anticipated that the findings presented in this study will foster an understanding of the business value that can be derived from Facebook by SMEs, especially in the case of developing countries like Pakistan.
\end{abstract}

Keywords: Small and medium enterprises, SME, Social media, Facebook, Business value, Multiple case study 


\section{Introduction}

Nowadays, social media have been pervasive for businesses as a tool for interacting directly with consumers, even reaching potential customers (Safko, 2010; Solis, 2010; Evans, 2012). This social media interaction resulted in increased levels of organizational learning on how to improve their offerings; named of value propositions (Vargo et al., 2008). There has been enough anecdotal evidence world widely, as well as research showing that social media marketing strategies have increased at an exponential rate, by generating business (Vargo et al., 2008) value such as the expansion of word-ofmouth (WoM), customer engagement, sales, and brand awareness (Safko, 2010; Solis, 2010). However, there is a dearth of literature on the business value of a particular social media application such as
Facebook in the developing countries situated in the Asia Pacific (Lee et al., 2010).

The analysis of internet penetration in Asian Pacific countries, as presented in Figure 1, reveals that there has been a higher proliferation of internet users, but despite achieving a higher internet penetration, the vast majority of the internet users $(80 \%)$ connect around one hour per day, and the length of one connection may just last for only 5 minutes (Teller, 2014). In contrary to higher internet penetration, the overall social media penetration in most of these countries is still very low. Moreover, most of the social media usage in these countries is made by individuals (mostly for fun related activities), and not by firms (for their official usage), which leads to the assumption that the firms have been not yet considered the use of social media as a strategic marketing tool for their businesses (Rohra, 2009).

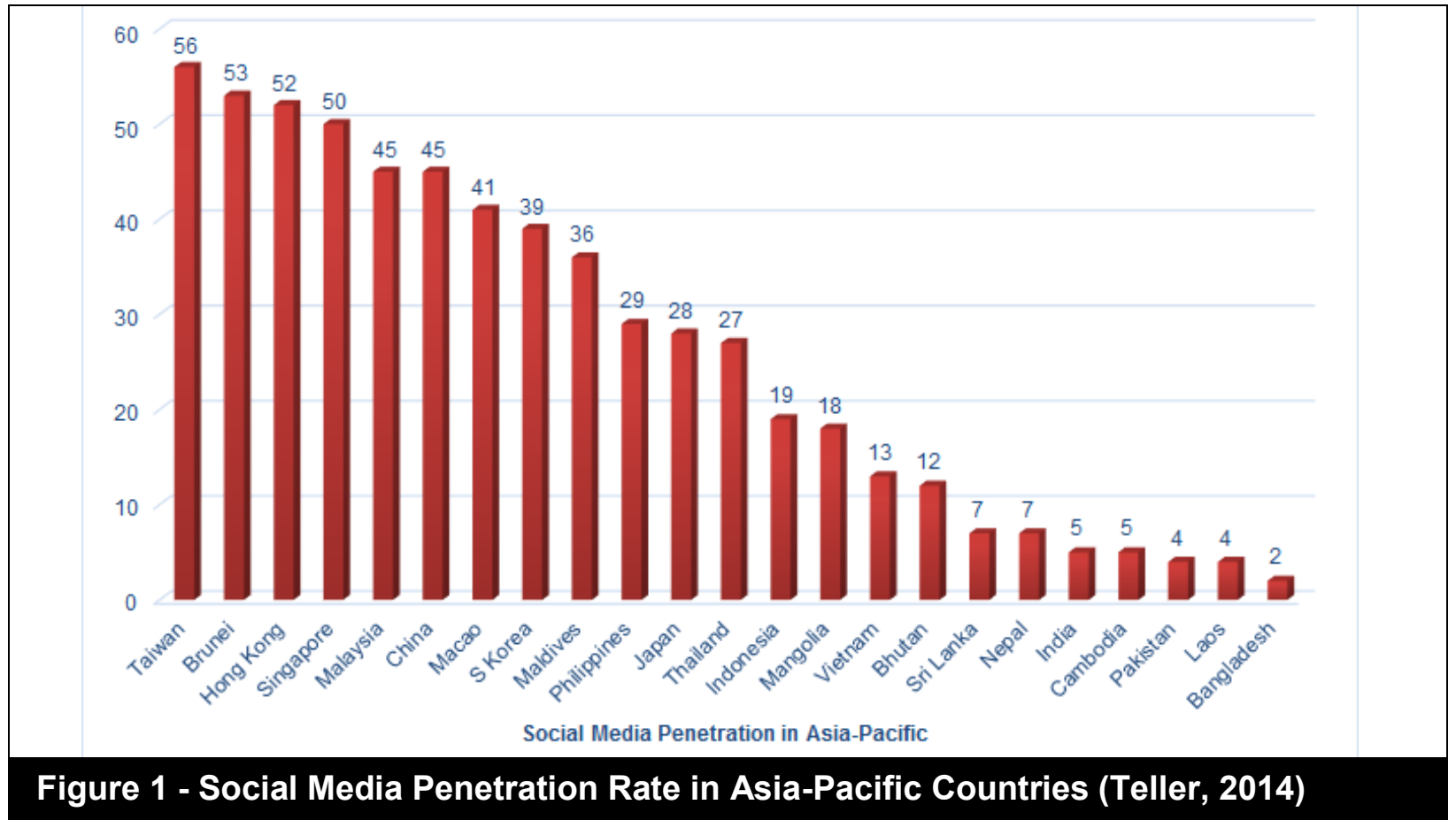

In the case of Pakistan, the country under this research, it has been noticed that the social media penetration has been far behind in comparison to the other countries of the region such as Taiwan with $56 \%$,
Brunei with 53\%, and Singapore with 52\% of social media penetration. Indeed, Pakistan just has $4 \%$ of social media penetration, being one of the three countries with the lower rates of social media usage 
together with Laos, and Bangladesh. Furthermore, it is noted standing that Facebook has been the most popular social media channel in Pakistan in comparison to other social media channels such as WhatsApp, Twitter, YouTube, and Linkedln (Teller, 2014). The Facebook Corporation was founded in February 2004, and to date, Facebook is one of the most successful social network websites in the world and has achieved more than 890 million daily active users. In addition, Facebook launched features for businesses to provide value to individuals, marketers, businesses and developers alike (Facebook, 2014). With this in mind, a large number of Facebook users have led firms especially the SMEs to view business opportunities such as the ability to communicate and promote their brands directly to their targeted audience, by using Facebook (Safko, 2010). This scenario then motivated the authors to conduct a study to investigate:

a) Why SMEs use Facebook? (referred as objectives behind the use of Facebook)

b) How they use Facebook? (referred as the Facebook marketing strategies) and

c) What are the business value (referred as business outcomes) captured from the use of Facebook?
This article attempts to answer these research questions. The structure of the rest of the paper is as follows: The first section provides the review of literature related to the use of social media by Pakistan-based SMEs. This is followed by the research framework. Thereafter, the methodology employed for this study is presented followed by an analysis of the results of the study. Finally, the paper concluded with the discussion section and the future research directions.

\section{Literature Review and Research Framework}

\section{Social Media in Pakistan}

The country of Pakistan has a population of 190 million people, with 30 million internet subscribers, showing that the Internet penetration reached $16 \%$ of its population. Although the social media penetration in Pakistan has been considered very low in comparison to other countries in this region (as shown in Figure 1 above). It is noticed that Facebook has been the most popular social medium in Pakistan, as shown in Figure 2. Currently, the Facebook users are more than double of next popular social media application; WhatsApp. Other popular social media applications like Twitter, YouTube and Linkedln are far behind Facebook in terms of their registered users (Teller, 2014).

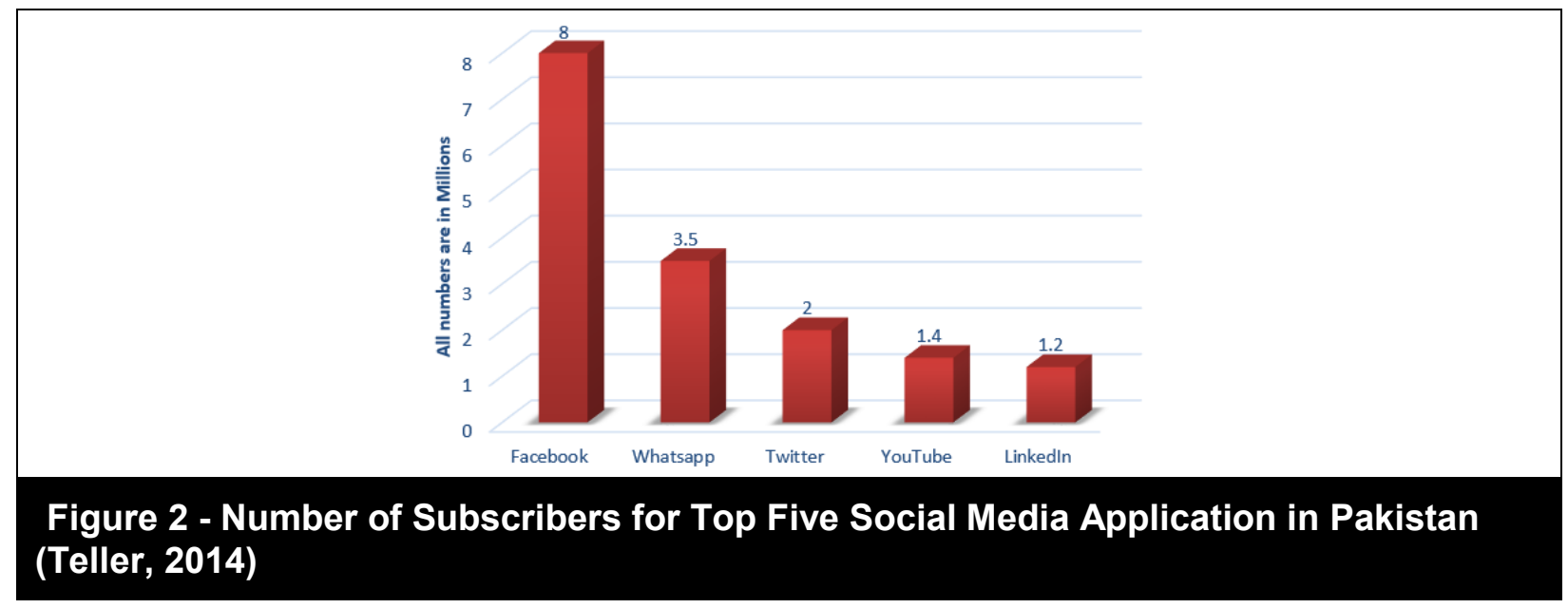


It is also important to mention that the statistics mentioned above are about individual subscribers and do not reflect the business use of these social media applications. Unfortunately, there is no official data available about the use of social media by the businesses (including SMEs) in Pakistan. However, it has been witnessed that there has been a growing interest in the adoption of Facebook marketing strategies by the SMEs in Pakistan.

\section{SME Sector in Pakistan}

Literature has defined SMEs by a wide variety of definitions and criteria. For example, (Verhees and Meulenberg, 2004) defined an SME as:

'a firm that is run and controlled under the direct supervision of the owner.'

According to the above definition, the SME sector was highly dependent of entrepreneurs. The notion of SME was also conceptualized according to the number of employees varying according to each region, and country (Verhees and Meulenberg, 2004; Dwivedi et al., 2007). For example, the USA threshold of number of employees to characterize an organization as an SME corresponded to 500 staff members, while this number is 200 in Australia, and 250 at the European Union. Other than the number of employees, some countries use other metrics to define the concept of SME such as, industry, ownership structure, and revenue (Wielicki and Arendt, 2010). In case of Pakistan, the Federal Cabinet (as part of the SME policy 2007) define SMEs based on the following metrics:
- Employment size up to 250 employees;

- Paid up capital up to PKR 25 Million (1 Pakistani Rupee (PKR) is approximately equal to 0.0096 USD);

- Annual Sales up to PKR 250 Million

For Pakistan, the SMEs represent the 'backbone of the industry', as the economy of this country largely depends on the SME sector. This sector, indeed, has provided a platform and a stimulus for the economic and social growth of Pakistan by significantly increasing the number of jobs available and in parallel contributing to the poverty alleviation. The growth of the SMEs is the most viable solution to combat the menace of poverty and unemployment in Pakistan, as the significance of this sector has been demonstrated by various statistics (Wielicki and Arendt, 2010; Bhutta and Sylva, 2015). For example, most recently, there has been estimative that there are approximately 3.2 million SMEs in Pakistan, which constitute over $90 \%$ of the industrial sector of the whole country. The SME sector has also hired nearly $78 \%$ of the nonagriculture labor force in the country and also contributing to the increase of more than $30 \%$ of the gross-domestic-product (GDP), and account for $25 \%$ exports of manufactured goods, while sharing $35 \%$ of local manufacturing added value; according to the Pakistan-based SME policy (SMEDA, 2007). The expected contribution and size of the Pakistan-based SME sector in 2018 has been formed by using existing data from the year of 2013. This data is published after every five years. Table 1 summarized this information as follows:

\section{Table 1 - Expected Contribution and Size of Pakistani SMEs (SMEDA, 2007)}

\begin{tabular}{|l|l|l|}
\multicolumn{1}{c|}{ Indicator } & \multicolumn{1}{c|}{$\mathbf{2 0 1 3}$} & \multicolumn{1}{c|}{$\mathbf{2 0 1 8}$} \\
\hline Employment & 14.85 Million & 25.00 Million \\
\hline Gross-Domestic-Product & \$73.95 Billion & \$193.5 Billion \\
\hline Number of Enterprises & 2.30 Million & 4.20 Million \\
\hline Exports & \$18.21 Billion & \$54.2 Billion \\
\hline
\end{tabular}




\section{Facebook Marketing}

After the advent of the digital marketing, firms have to manage and control simultaneous online marketing strategies (Solis, 2010; Li and Bernoff, 2011; Qualman, 2011). Despite the challenges of measuring online marketing strategies and expenditures with the allocation of both operant, and operand resources; research increased at an exponential rate by showing positive business outcomes from the use of social media such as Facebook and Twitter (Li and Bernoff, 2011). Relevant literature suggests that firms have used social media such as Facebook for generating different and multiple positive business outcomes such as 'advertising', 'promotion', 'increased word-of-mouth' (WoM), and 'customer engagement' (Stockdale et al., 2012). Since the launch of 'Facebook for Business' in 2014, Facebook advertised that by creating a business page on Facebook would assist firms in driving either online, and local sales, as well as brand awareness.

In general, Facebook marketing strategies can be implemented for generating various business outcomes, such as, (in alphabetical order) 'advertising' (Holzner, 2008; Vander Veer, 2011), 'brand awareness' (Treadaway and Smith, 2012; Shen and Bissell, 2013), 'brand loyalty' (Shen and Bissell, 2013), 'customer engagement' (Treadaway and Smith, 2012; Coursaris et al., 2013), 'events management' (Holzner, 2008) and 'increased sales'(Holzner, 2008; Vander Veer, 2011; Hsu, 2012). It is imperative to note that 'advertising' has been the most popular business outcome achieved by using Facebook for business, followed by 'increase in sales' (Holzner, 2008; Hsu, 2012). Though the findings mentioned above are not directly applicable to the SMEs in developing countries, they do suggest that the Pakistan-based SMEs will have at least partially, similar business outcomes such as 'advertising', and 'customer engagement'. The review of relevant literature also suggests that there is no clear differentiation of business objectives from business outcomes (alternatively used for the term business value) as in some of the cases both objectives and outcomes will be achieved by turning both objectives and outcomes in the same constructs, while in other cases, the business objectives could generate different, or even additional business outcomes. For example, the business objectives for using Facebook for 'advertising' and 'customer engagement' could generate the same business outcomes as of 'advertising' and 'customer engagement', as well as, further business outcomes such as 'increased brand awareness', and 'increase in sales'. The review of literature also suggests that there is a lack of detailed information about how to implement Facebook marketing strategies such as the practices of interacting one-to-one with consumers, by personalizing both business-to-consumer (B2C), and consumer-to-business (C2B) communications, and sharing content of interest.

\section{Research Framework}

The theoretical framework presented in this study encapsulate the overall process of generating business value for Pakistanbased SMEs through Facebook marketing. It is suggested that the process of generating business value starts with the organizations having some expectations to meet or the benefits to achieve through the use of Facebook. Similarly, the organizations need to devise the best practices to use Facebook so they can achieve the expected benefits. Finally, the use of Facebook would yield some outcomes that could be same, less or more than the expected benefits. The proposed framework has the three key components such as (a) the expected 'business objectives', (b) the 'marketing strategies', and (c) the 'business value' - as shown in Figure 3 below. 


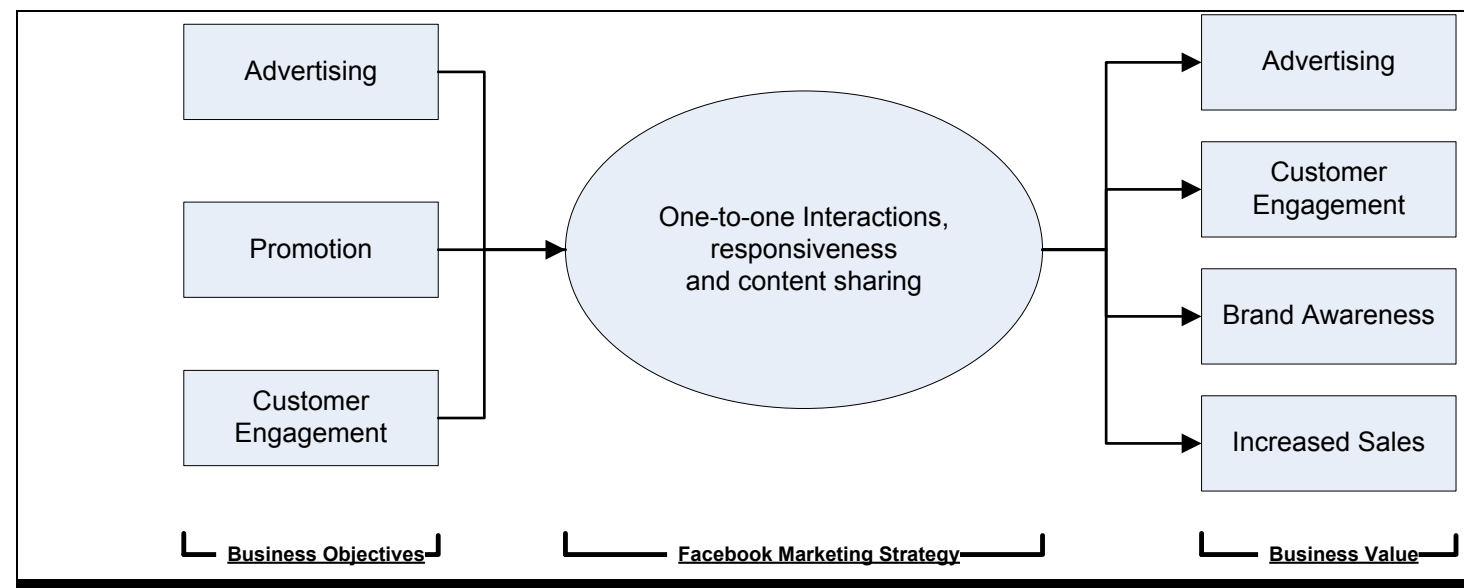

Figure 3 - The Theoretical Framework of Business Value of Facebook for SMEs

The term 'Business Objectives' refers the rationale behind using. These are the intended uses and expected benefits that the case organizations aimed to achieved through Facebook marketing. The research Framework presented in Figure 3 suggests three business objects of the Facebook marketing. First objective is 'advertising' the activities of producing information for promoting the sale of products or services through Facebook connections. Second 'promotion' in social media is promoting exclusive deals for the Facebook connection. Last but the most important revenue generating objecting is engaging with customers - reaching out to a wider pool of Facebook users and establishing constant and valuable connections with them.

'Facebook Marketing Strategy' refers how Facebook could be used to achieve the expected business objectives. These are the best practices employed by the organizations to make their Facebook marketing efficient and effective. As shown in Figure 3, the proposed marketing strategies include 'one-to-one interactions' with the customers through customized and personalized response, 'responsiveness' in terms of timely and appropriate response, and 'content sharing' in terms of making the relevant information available to the customers. It is suggested that these Facebook marketing strategies would assist the case organizations in achieving their intended business objectives such as 'advertising', 'promotion' and 'customer engagement'.

'Business Value' refers the actual benefits and outcomes (both financial and nonfinancial benefits) resulted from the use of Facebook. The outcomes of the Facebook marketing could return the exact business objectives or even more benefits than expected initially. Therefore, it is proposed that a successful Facebook marketing strategy could result more than expected benefits such as 'advertising', 'customer engagement', 'brand awareness' and 'increased sales'.

\section{Methodology}

This paper investigates the effectiveness of Facebook marketing strategy and its impact on generating business value for SMEs of Pakistan. Therefore, we selected the case study research method as it best suited the research objectives posed from an analytical standpoint, as well as from a pragmatic standpoint of access to the research field. The case study research method has advantages over other available research methods (Yin, 2013) when the research question posed is of the type 'how' or 'why'. Moreover, the case study method is also well suited for research projects in which the researchers 
have minimal or non-existent control over the research objects that are being investigated. Given the nature of our research question 'how' and the pragmatic considerations of researching five SMEs, we argue that the selection of the case study research method is appropriate. To operationalize the research methodology, we selected five SMEs from the two largest metropolitan cities (Karachi and Lahore) of Pakistan. Five cases might not be sufficient for statistical generalization but have used successfully for analytical generalization (Ahmed 2014), that is, aligned with the aim of this study. Data was collected from semistructured, face to face interviews with the business owners or key decision makers of the SME between December 2014 to February 2015. The use of semi-structured interviews ensures a degree of consistency in the information collected from the different firms but still has enough flexibility to allow for new, unexpected or interesting information to emerge during the interview. Interviews were conducted in Urdu (Pakistan's national language) that were later transcribed and translated into English by one of the authors. Before the transcribed data was coded manually, it was verified by the other author of this paper (Please note that both authors are proficient in Urdu and English). Once the data was translated into English, it was analyzed by pattern matching technique.

The following steps were taken to select the most appropriate sampling strategy for this study:
- In the absence of an online database of SMEs, a list of local SMEs was obtained from the Chamber of Commerce in Lahore and Karachi.

- Based on the list of SMEs, the firms that had active Facebook profile were shortlisted.

- Out of the shortlisted firms, eighteen firms (nine from each of the two cities) were contacted to participate in this research.

- Nine out of eighteen firms expressed their willingness to participate in this research, whereas three of them withdrawn their participation at later stages;

- In-depth interviews were conducted with six firms, whereas the five most comprehensive interviews are included in this study;

- All interviews were conducted face-toface with the owners or the key decision makers of the selected firms and recorded on a digital audio device before transcribed and translated into the English for coding and data analysis.

- In order to protect the identity of the participating firms, their business names were de-identified and referred as the cases $A, B, C, D$, and $E$.

Table 2 presents an overview of the participating firms and their business Facebook pages:

\begin{tabular}{|c|c|c|c|c|c|c|c|}
\hline \multirow{2}{*}{$\begin{array}{l}\text { Case } \\
\text { Code }\end{array}$} & \multicolumn{3}{|c|}{ OVERVIEW OF THE BUSINESS } & \multicolumn{4}{|c|}{$\begin{array}{l}\text { OVERVIEW OF THE FACEBOOK PAGE } \\
\text { (as of May 2016) }\end{array}$} \\
\hline & Business Type & $\begin{array}{c}\text { No. of } \\
\text { employees }\end{array}$ & $\begin{array}{c}\text { Established in } \\
\text { (year) }\end{array}$ & $\begin{array}{l}\text { People } \\
\text { talking }\end{array}$ & $\begin{array}{l}\text { People } \\
\text { checked }\end{array}$ & $\begin{array}{l}\text { No. of } \\
\text { likes }\end{array}$ & $\begin{array}{l}\text { No. of } \\
\text { reviews }\end{array}$ \\
\hline $\mathrm{A}$ & Restaurant & 25 & 2009 & 5,207 & 28,103 & 156,096 & $7.8 \mathrm{k}$ \\
\hline$B$ & Fashion boutique & 20 & 2010 & 41 & - & 30,198 & 769 \\
\hline C & Beauty saloon & 9 & 2011 & 2,689 & 1,983 & 133,347 & 50,06 \\
\hline $\mathrm{D}$ & Cafe' & 16 & 2009 & 381 & 21,533 & 51,780 & $1.3 \mathrm{k}$ \\
\hline$E$ & Retail /Sports & 5 & 2009 & 587 & 240 & 17,629 & 162 \\
\hline
\end{tabular}




\section{Data Analysis}

\section{Background Story: Case $A$}

Case $A$ is a family owned fast-food restaurant established in the year 2009 as a small stall on a busy street in Lahore. During the first year of its inception, it was as small as to accommodate a maximum of 12 people at a time. During that time, the business struggled to sustain and was unable to generate any profit at all. In the second quarter of 2011, the owner of this restaurant decided to close down the business because of poor performance and considered it as 'a dead loss'. All that frustration resulted in the relocation of the business to two different places in a single year; yet not generating any different business outcome. Eventually, the owner of the business had an idea to use Facebook for online advertisement. A Facebook page was then setup to advertise the business. Unfortunately, even this initiative did not offer any better business outcome. A second idea emerged for the usage of Facebook for marketing purpose. Being inspired by the iTunes model (99c flat rate for each song); a flat price (what the owner called as 'FLAT PRICE - NO RISK IN TRYING!!!') was introduced for all the burgers served in the restaurant. The 'Flat Price offer' was put on the Facebook page, and it did bring instant results. By the next day, consumers become quite curious, and started coming to the restaurant to try different burgers taking the 'Flat Price offer'. The owner of the business realized the value of the Facebook marketing strategy very quickly, and took it quite seriously. He started dedicating more time to manage his Facebook marketing campaign by making sure that the contents on the Facebook page were accurate and updated. He also realized that Facebook is a communication channel to receive feedback, complaints and suggestions from customers and as such it is an efficient marketing channel for customer engagement. He learned that he had to be able to accept criticism and to respond to it, by addressing the ground issues in the restaurant, the owner attained business responsiveness. In one of his answers, the owner of case A stated as:

\section{"listening to your customers is not enough. They would like to see some actual things happening. If you just listen and don't act, people will stop giving you the feedback that is absolutely not what you aim for"}

By actively responding to the feedback of the customers, he turned some unsatisfied customers into satisfied customers quite quickly and resulted into increased customer satisfaction. The owner of this firm also stressed the importance of personalized and customized communication on Facebook. He was not in favor of outsourcing the social media campaign to the commercial media agencies because according to him:

"these [social media] agencies didn't look into the depth of your business and without getting the feeling and understanding of the business they just offer a 'standard package' such as how many posts will be uploaded per day or week and you will get this much of likes etc."

He further added as:

"generally they [social media agencies] don't make an effort to understand the needs of your business. This strategy may work for large organizations but not for SMEs. For large organizations this could be just one channel of their communication out of many but for SME it is critical. For SME you need person who not only devise your strategy but also understand your business inside out"

Though, the owner of the Case A received professional services for graphics and integrated themes for his business Facebook page, he decided to manage all the contents by himself. He also managed all communication by himself because he rightly thought that he was the best person to know about his business. Consequently, 
the owner realized the value of Facebook for his business regarding sales growth and increase in number of the 'likes' on the business Facebook page. The business objectives, Facebook marketing strategies, and business outcomes are reported in Tables 3 below.

\section{Background Story: Case B}

Case $B$ is a fashion boutique established in early 2010 in a highly populated area of Karachi, and focuses on fulfilling the clothing needs of female clientele. Initially, the business had a website containing a photo gallery of products on sale, their price range, online purchasing facility, and business's contact details. Later on, the business launched a Facebook page that included a photo gallery of various products and used as an avenue to engage with customers by responding to their queries and comments. The Facebook page of this business is controlled and managed by the owner and one of her personal assistants (PA). The PA is responsible to upload content such as pictures of clothing, their description and prices. In addition, the PA also assists in answering the most commonly asked questions on Facebook, whereas the complicated inquiries, criticisms, and complaints are directed to the owner of the business. In contrast to Case A, where the business objectives appeared through an 'experimental way', the Case $B$ has set up the Facebook page with the business objectives of advertising and engaging with customers. Moreover, the owner already recognized that the Facebook brought the outcome of enhanced WoM, and the notion of WoM was indeed, described as a positive peer recommendation, and discussion about a brand, product and/or service. The owner of this business heavily relied on the value of WoM, as she observed that the vast majority of the new customers came to the physical store because of the recommendations of existing customers. Talking about the importance of WoM, the owner of this business said: "my customers are my marketers. They bring more credible customers [through WoM] to my business than any other marketing channel... I just need to make sure that my existing customers remain happy. If they are happy, they will steer dozens of new customers in my way"

The e-WOM could be seen through the Facebook page, where customers 'liked' the post, or clicked on the 'share' button of the Facebook page, by exposing the brand to a further network of consumers. Ultimately, the expected outcome of the Facebook marketing strategies was to extend e-WoM and to direct customers to the retail store where they could see and try the clothing before purchasing; in other words, the expected outcome was to increase in sales. According to the owner of this business, the launch of Facebook page resulted into (approximately) 30\% increase in customer acquisition and a substantial reduction in the overall marketing expenses. The business objectives, Facebook marketing strategies, and business outcomes are reported in Table 3 below.

\section{Background Story: Case C}

Case $\mathrm{C}$ is a beauty salon providing services to the local community in the central Lahore. The business was established in the year of 2011. During the first year, it had only two full time employees, whereas by the end of 2014 there were nine staff members working full-time in this business. During the first two years of its inception, the business mainly relied on traditional media (such as local newspapers and magazines) for the advertisement and promotion of its products and services. In December 2012, the owner of the business realized that the business marketing strategy (through traditional media) was not bringing enough satisfactory results. High marketing expenses, and poor brand awareness were the key issues with the business marketing strategy. This led the owner to switch from traditional media to social media for the advertisement and promotion of the business. As a result, the 
advertisement and marketing campaign was outsourced to a digital marketing agency that launched the first Facebook page for this business in early 2013. During the first four months of the launch of the Facebook page, the digital marketing firm created the business profile on Facebook, posted regular contents, maintained the overall look and feel of the page and even responded to the customers on the behalf of the business. Initially, this business witnessed immediate positive impact as a result of the launch of the Facebook page. More customers were visiting the saloon and spreading WoM about various products, and services on the Facebook page. According to the owner of this business:

"the launch of Facebook page for [business name] was very well received by the customers and general public. It helped to bridge the communication gap between my business and the customers in an effective and convenient manner"

By mid-2013, the owner realized that there was a gradual decline in the customer engagement on the Facebook page, as fewer consumers were visiting the Facebook page, spreading WoM, and visiting the saloon. Because of the decrease of the customer engagement on the Facebook, the owner decided to take control of the Facebook page by directly interacting with customers. According to the owner,

"this personal touch' proved valuable and consumers started to come back by visiting both the Facebook page, and the saloon".

Since then the Facebook page is maintained by the owner herself. She is spending a fair amount of her time to upload latest contents on the Facebook page, replying to the comments of the customers through customized and personalized responses, engaging with them and introducing new products and services in the saloon based on the customers' feedback. The owner said that "the length of time spent for maintaining the Facebook page was worthwhile, as it resulted in better business outcomes"

To date, the business outcomes surpassed the business objectives, as not just only the marketing expenses on Facebook reduced to 'none' compared to PKR 100,000 per year on ads in newspapers and magazines, but, as a result of the Facebook marketing strategies, the business is currently in process of opening another branch in the adjacent city of Gujranwala.

"this initiative [opening of a new branch] is taken purely based on the feedback and suggestions received from the customers of the saloon on the Facebook page" claimed by the owner.

The business objectives, Facebook marketing strategies, and business outcomes are reported in Table 3 below.

\section{Background Story: Case D}

Case $D$ is a local café and ice cream parlor and is currently very popular especially among teenage and young adults. The business was started in late 2010. Initially, the business failed to get enough response from consumers and reported the significant loss at the end of first financial year. It was a tough call for the owner to continue the business after such a financial loss. However, he decided to keep the business open for another year and took some steps to improve the business by investing in the renovation of the café to present it according to the vibe of the targeted clientele - young adults. In addition, he launched a huge marketing campaign on both traditional and contemporary online media such as Facebook. Regarding marketing, $2 \%$ of the business profit was allocated for marketing related expenses (including both paid advertising in traditional media, and on the paid contents of Facebook). These steps resulted in significant improvement and the business witnessed considerable sales growth just after the six months of the implementation of the improved marketing campaign. 
Since the implementation of the Facebook brand-community, both above-the-line (ATL), and below-the-line (BTL) marketing have been taken very seriously by the owner of this business. The term named of abovethe-line marketing has been described as marketing strategies that have been outsourced to marketing agencies, while the notion of below-the-line marketing has been defined as marketing strategies that have been under the control of the business owners. The importance of marketing was highlighted as:

"marketing is the oxygen for my business. Without marketing, my business cannot survive", said the business owner

The owner of this business was very innovative and was not afraid of experimenting new marketing strategies on Facebook. In order to attract more people to visit the Facebook page, he occasionally announces 'special offers' that are exclusive to the Facebook users (announced only on the Facebook page). In detail, he promotes special offers on Facebook, such as 'free cone days' on important events such as the 'Eid-ul-Fitr' and the 'Eid-ul-Adha' (two major national festivals in Pakistan). Such initiatives encourage the people to stay connected on Facebook page that is indeed the first requirement to make Facebook campaign effective.

In summary, the key goal of the business was to be sustainable despite of the initial loss. In order to accomplish that goal, a marketing campaign was launched both in the traditional media and on the Facebook for customer engagement, and brand awareness. Similar to the Case $\mathrm{C}$, this case organization (Case D) had business outcomes that surpassed the business objectives, as not just only the business kept open and become sustainable, but besides that, it had an increase in brand awareness, and sales. The business objectives, Facebook marketing strategies and the business outcomes for Case $D$ are reported in Table 3 below.

\section{Background Story: Case E}

Case $E$ is a retail store that sells sports motorbikes and their accessories. The store was established in 2009 in the central Lahore and deals with a niche market of motorbike enthusiasts. Initially, the owner underestimated the true volume of the potential customer-base and thought that there were only limited numbers of potential customers interested in the product range of the store. However, in 2011 he learned that there were much more consumers who were interested in buying sports motorbikes than he initially anticipated. The customers interested to know the characteristics of motorbikes, their accessories, and once they obtained the appropriate information, they tended to conclude the purchase. To reach out to potential customers, the business owner launched a Facebook page at the end of 2011 with the objective of engaging consumers by sharing expert information and advertising. Since the launch of the Facebook page, he witnessed growing interest of consumers wishing to learn the features of new motorbikes and their price range, as well as; they seek for expert recommendations on the products on sale. In parallel, the consumers were also providing feedback and suggestions to the business about their needs and experiences. For instance, the people were so engaged on the business's Facebook page that they suggested hosting events such as 'ridetogether', and motor shows that turned into very successful activities to attract new customers. According to the owner of this business:

"Facebook helped me to reach many people and some of them are now my customers"

He further stated as:

"on Facebook, we have a community in which people know each other, they talk to each other, and they help each other when it comes to superbike"

The business objectives, Facebook marketing strategies, and business 
outcomes for this business are reported in Table 3.

The following section reports the research findings by comparing the business objectives, the Facebook marketing strategies, and the business outcomes among the five Pakistan-based SMEs.

\section{Results}

From the background stories presented above, the analysis of the interviews' data suggests that 'advertising', 'promotion' and enhancing the 'customer engagement' were the key business objectives behind the use of Facebook marketing. There is significant support (from all the five cases) for 'advertising' and 'customer engagement' as the key objectives that these organizations wanted to achieve through Facebook marketing. Moreover, all case organizations perceived Facebook as the right platform where they can reach out to a wider pool of customers and establish network connections with them that can be used to advertise their products and services. However, only two cases (Case A and Case D) intended to promote their goods and services exclusively to their Facebook connections, whereas there is no support for 'promotion' as a business objective from the remaining three case organizations including Case $\mathrm{B}, \mathrm{C}$ and $\mathrm{E}$.

To achieve the above-mentioned business objectives, all the five cases shared and updated related contents on their Facebook pages on a continuous basis, while four out of the five cases (Case A, B, C and Case E) also implemented a strategy in maintaining one-to-one interactions with their customers. This means that the owners of these cases were directly interacting with the consumers through customized and personalized communication. Thus, customers felt they have been heard by the organizations and it had a strong impact on creating positive business-customer relationships. These interactions turned both $\mathrm{B} 2 \mathrm{C}$, and $\mathrm{C} 2 \mathrm{~B}$ into personalized communications, and therefore, the marketing strategies of 'oneto-one interactions', and 'content sharing' served as the key enablers of their successful Facebook marketing strategy. Two of the five organizations (Case $A$ and Case C) also became more responsive, as they reacted to the customer feedbacks, by conducting changes according to the suggestions received from the customers. The Table 3 presents the Facebook marketing strategies conducted by the owners of the selected SMEs, as in all cases the owners were also the moderators of the Facebook brand-community.

The analysis of the case organizations also revealed some interesting findings when it comes to the business value derived from the Facebook marketing strategies. Despite the very low Facebook penetration in Pakistan, the results of this study suggest that the use of Facebook brought significant positive business outcomes. For instance, two of the three business objectives such as 'advertising', and 'customer engagement' were attained using Facebook. In addition, all the five cases witnessed increase in brand awareness, and sales growth. The analysis of data collected from case organizations suggests that the Case $\mathrm{A}$ and Case $C$ were the two most successful cases as Case A established itself as a successful business, with the $100 \%$ increase in revenue in one financial year while the Case $\mathrm{C}$ led to open a new business outlet that is primarily resulted from a successful Facebook marketing campaign. Other than the Case $A$ and Case $C$, the owner of the Case $B$ mentioned that having a presence in Facebook helped spreading e-WoM, resulted an increase of around 30\% in the customer acquisition. The case $\mathrm{D}$, despite of keeping collateral marketing strategies by maintaining both traditional and online media, as well as the case $\mathrm{E}$ that promoted brand events via Facebook claimed significant increase in their business value. Table 3 listed the business value derived from the Facebook marketing strategies in all five cases. 


\begin{tabular}{|c|c|c|c|c|c|c|}
\hline & & $\begin{array}{c}\text { Case } \\
\text { A }\end{array}$ & $\begin{array}{c}\text { Case } \\
\text { B }\end{array}$ & $\begin{array}{c}\text { Case } \\
\text { C }\end{array}$ & $\begin{array}{c}\text { Case } \\
\text { D }\end{array}$ & $\begin{array}{c}\text { Case } \\
\text { E }\end{array}$ \\
\hline \multirow{3}{*}{$\begin{array}{l}\text { Business Objectives } \\
\text { (Perceived benefits) }\end{array}$} & Advertising & $x$ & $\mathrm{x}$ & $\mathrm{X}$ & $\mathrm{X}$ & $\mathrm{X}$ \\
\hline & Promotion & $x$ & & & $x$ & \\
\hline & Market reach & $\mathrm{x}$ & $\mathrm{x}$ & $x$ & $\mathrm{X}$ & $x$ \\
\hline \multirow{3}{*}{$\begin{array}{l}\text { Marketing Strategies } \\
\text { (Facebook marketing } \\
\text { approaches) }\end{array}$} & One-to-one interactions & $\bar{x}$ & $\bar{x}$ & $\bar{x}$ & & $\bar{x}$ \\
\hline & Responsiveness & $x$ & & $x$ & & \\
\hline & $\begin{array}{l}\text { Share \& Update Business } \\
\text { Content }\end{array}$ & $\mathrm{x}$ & $x$ & $\mathrm{x}$ & $\mathrm{x}$ & $\mathrm{x}$ \\
\hline \multirow{4}{*}{$\begin{array}{l}\text { Business value } \\
\text { (actual benefits) }\end{array}$} & Advertising & $\mathrm{X}$ & $\mathrm{X}$ & $\mathrm{X}$ & $\mathrm{x}$ & $\mathrm{x}$ \\
\hline & Customer Engagement & $x$ & $\mathrm{X}$ & $\mathrm{X}$ & $\mathrm{X}$ & $\mathrm{X}$ \\
\hline & Brand Awareness & $\mathrm{X}$ & $\mathrm{X}$ & $\mathrm{X}$ & $\mathrm{X}$ & $\mathrm{X}$ \\
\hline & Sales & $x$ & $x$ & $\mathrm{x}$ & $\mathrm{x}$ & $\mathrm{x}$ \\
\hline
\end{tabular}

\section{Discussion}

The business objectives of the five SMEs as of 'advertising' and 'engaging with customers' appeared as results of the experimental practices on Facebook rather than being planned and anticipated by the owners. This finding follows the trend that the owners of SMEs act in their majority by showing a lack of mindful adoption. The notion of mindful adoption has been described as a business strategy where the SMEs have defined clear business objectives (Chua et al., 2009), by identifying problems that must be addressed such as reaching the appropriate target market (Lacho and Marinello, 2010). For example, by 'engaging the customers', the Facebook marketing strategies also contributed to the increase of 'brand awareness' in all the five cases. For the Case $A$, the numbers of Facebook 'likes' increased from two thousand to 130,000 'likes' in 2 years (from 2011 to 2013), while for the Case C, the number of 'likes' on Facebook page increased from 21,000 to 60,000 during the first quarter of 2014 .

Despite the marketing literature claimed that business values derived from the use of Facebook were 'customer loyalty', and 'events' management', those results were not apparent in this study. For example, the owner of the Case A was the only one who mentioned that Facebook enhanced 'customer satisfaction', which is a notion related enhancing 'customer loyalty' (Shen and Bissell, 2013). However, the result of increased sales could lead to the notion of 'customer loyalty', as this concept means repeated customer purchases (Shen and Bissell, 2013), and the owners of all the five case organizations suggested that Facebook increased their volume of sales. However, the validation that Facebook marketing strategies increase 'customer loyalty' needs further investigation because the growth in sales could also relate to 'customer acquisition', rather than to 'customer loyalty'.

It is interesting to note that only one of the five cases used Facebook for 'promoting events' (N.B. 'promoting events' is different from 'promotion' of products), and this case may lead to the fact that Facebook recently implemented a tool for managing events, and as such, this functionality may deserve further advertising. During the interviews with the case organizations, none of the interviewees mentioned the use of Facebook tool for managing an event. From an alternative viewpoint, the Pakistan-based SMEs may not organize and promote events as this marketing strategy may increase business costs. This is one of the facts that need further investigation. From the perspective of business costs, the 
owners of the cases $B$ and $C$ mentioned that Facebook caused a reduction in the marketing expenditures specifically the owner of the case $\mathrm{C}$ that claimed that the

\section{"marketing expenses on Facebook reduced to none as compared to Rupees 100,000 per year on ads in newspapers and magazines".}

Despite existing literature claiming that social media reduced marketing related expenditures (Safko, 2010; Solis, 2010; Evans, 2012), the five cases evaluated in this study have not considered owners time to manage the Facebook page, as such, the length of their time spent on Facebook as a 'business cost'. This characteristic of the management of SMEs turned then, difficult to measure if the Facebook marketing strategies really decreased the business costs, but still, a reduction in the overall business costs may be suggested using Facebook by the SMEs.

\section{Conclusion}

This paper examined the business value of Facebook for Pakistan-based SMEs, by conducting multiple case study analysis of five SMEs operating in different industries. The research results suggest that the management of the Facebook marketing strategies was important to achieve business value. It was imperative to note that just having a Facebook brandcommunity did not generate business value. In all the five case organizations evaluated in this paper, the owners of the businesses suggested that the 'personal touch' and 'personalization' in the one-to-one interactions with the customers was a key factor for the success of the Facebook marketing strategies. Especially noticed in the cases $C$, and $E$, when these SMEs initially outsourced the Facebook marketing strategies to digital marketing firms, their businesses failed to engage with customers and hence failed to achieve the expected business outcomes from Facebook. The results of this study also showed that businesses should listen to their customers on social media and act upon the customers' feedbacks. Therefore, the SMEs should be ready to accept complains and criticisms to increase business performance. On the opposite, it may be possible that if the customers do not see actions resulting from their comments posted on Facebook, they probably would stop interacting by disengaging with the businesses - as was reported by the Case $A$.

Although this paper successfully addressed the process of generating business value from Facebook marketing strategies in the Pakistan-based SMEs, there has been areas that still need further investigation. For example, it has been necessary to examine case organizations that were not successful with the use of Facebook and to investigate the reasons behind their failure. This aspect could help to gather a better understanding about potential causes of failure. A further research question that is worth to address corresponds to the examination of the possibilities of comparing the research findings to other social media channels such as Twitter.

In summary, this paper has contributed to academia, by adding further knowledge on marketing strategies in Facebook for Business and their outcomes, as business owners of SMEs have lacked managerial guidance on how to implement, and maintain Facebook brand-communities, especially in the developing countries. In addition, differently from the existing models that showed the use of social media (in general) by organizations this theoretical framework, to the best of our knowledge, has been the first model that showed the antecedents, the practices, and the consequences of using Facebook (exclusively) for business purposes. 


\section{References}

Ahmed, A. (2014). "An Empirical Investigation of Task-Technology Fit: Context of RFID in Disaster Management." Asia Pacific Journal of Information Systems, 24(3), pp. 345370.

Bhutta, S. M. and Sylva, K. (2015). "Health Education Classroom Practices in Primary Schools: An Observational Study From Pakistan." Global Journal of Health Education and Promotion, 16(2).

Chua, A., Deans, K. and Parker, C. (2009). "Exploring the types of SMEs which could use blogs as a marketing tool: a proposed future research agenda." Australiasian journal of information systems, 16(1), pp. 117-136.

Coursaris, C. K., Van Osch, W. and Balogh, B. A. (2013). A Social Media Marketing Typology: Classifying Brand Facebook Page Messages For Strategic Consumer Engagement. ECIS.

Dwivedi, Y. K., Khoumbati, K., Williams, M. D. and Lal, B. (2007). "Factors affecting consumers' behavioural intention to adopt broadband in Pakistan." Transforming Government: People, Process and Policy, 1(3), pp. 285-297.

Evans, D. (2012). Social media marketing: An hour a day, John Wiley \& Sons.

Facebook (2014). Facebook Annual Report 92.

Holzner, S. (2008). Facebook marketing: leverage social media to grow your business, Pearson Education.

Hsu, Y.-L. (2012). "Facebook as international eMarketing strategy of Taiwan hotels." International Journal of Hospitality Management, 31(3), pp. 972-980.
Lacho, K. J. and Marinello, C. (2010). "How small business owners can use social networking to promote their business." The Entrepreneurial Executive, 15, pp. 127.

Lee, S., Park, G., Yoon, B. and Park, J. (2010). "Open innovation in SMEsAn intermediated network model." Research policy, 39(2), pp. 290-300.

Li, C. and Bernoff, J. (2011). Groundswell: Winning in a world transformed by social technologies, Harvard Business Press.

Qualman, E. (2011). "How social media transforms the way we live and do business." Ipswich, MA: Business Book Summaries.

Rohra, C. L. (2009). "Comparative Analysis of SMEs Policies of Asian Countries with Reference to Pakistan." IJCRB: 36.

Safko, L. (2010). The social media bible: Tactics, tools, and strategies for business success, John Wiley \& Sons.

Shen, B. and Bissell, K. (2013). "Social media, social me: A content analysis of beauty companies' use of facebook in marketing and branding." Journal of Promotion Management, 19(5), pp. 629-651.

SMEDA (2007). SME Led Economic Growth - Creating Jobs and Reducing Poverty. SME Policy, Small and Medium Enterprise Development Authority, Government of Pakistan.

Solis, B. (2010). Engage: The complete guide for brands and businesses to build, cultivate, and measure success in the new web, John Wiley \& Sons.

Stockdale, R., Ahmed, A. and Scheepers, H. (2012). Identifying Business Value From The Use Of Social Media: An Sme Perspective. PACIS.

Teller, S. (2014) "30m Internet Users in Pakistan, Half on Mobile." 
Treadaway, C. and Smith, M. (2012). Facebook marketing: An hour a day, John Wiley \& Sons.

Vander Veer, E. A. (2011). Facebook: the missing manual, " O'Reilly Media, Inc.".

Vargo, S. L., Maglio, P. P. and Akaka, M. A. (2008). "On value and value cocreation: A service systems and service logic perspective." European management journal, 26(3), pp. 145152.

Verhees, F. J. and Meulenberg, M. T. (2004). "Market orientation, innovativeness, product innovation, and performance in small firms." journal of small business management, 42(2), pp. 134-154.

Wielicki, T. and Arendt, L. (2010). "A knowledge-driven shift in perception of ICT implementation barriers: Comparative study of US and European SMEs." Journal of Information Science, 36(2), pp. 162174.

Yin, R. K. (2013). Case study research: Design and methods, Sage publications.

\section{About the Authors}

Ashir Ahmed is a lecturer of Information Systems at Swinburne University of Technology, Australia. He has earned his $\mathrm{PhD}$ in Information Systems from Monash University, Australia. His research interests focus on the role of technologies such as IT and Web 20/Web 3.0 for creating positive social impact. Some of his research projects include the use of social media for suicide prevention, evaluating the role of community consultation for anti-radicalization through e-education, and developing the framework for using Web 2.0 in disaster management. He has published his research findings in leading journals and conferences such as Pacific Asia Journal of the Association for Information Systems (PAJAIS), International Conference on Information Systems (ICIS), European Conference on Information Systems (CIS), Hawaii International Conference on System Sciences (HICSS) and the Pacific Asia Conference on Information Systems (PACIS).

Mubasher Ibrahim completed his Master's degree from Hailey College of Commence, University of the Punjab, Pakistan. He has worked on various research projects related to the online industrialization in Pakistan and how it can be improved through social media applications such as Facebook. 